\title{
ARTEMIS EPHESIA IN APULUM BIOGRAPHY OF A ROMAN BRONZE STATUETTE
}

\author{
CSABA SZABÓ*-RADU OTA**-MARIUS MIHAI CIUTĂ***
}

\author{
*University of Pécs \\ Rókus u. 2. M épület, H-7624 Pécs Hungary \\ Max Weber Kolleg \\ Nordhäuser Str. 74, 99089 Erfurt, \\ szabo.csaba.pte@gmail.com \\ ** National Museum of Union, Alba Iulia, \\ Str. Mihai Viteazu, nr. 12-14 Alba Iulia, Romania \\ eractum@yahoo.com \\ *** Lucian Blaga University, Sibiu \\ Bulevardul Victoriei 10, 550024 Sibiu, Romania \\ mariusciuta@yahoo.com
}

In honorem Robert Fleischer 75

\begin{abstract}
The first known representation of Artemis from Ephesus in Dacia was recovered in the spring of 2006, the small bronze statuette being part of one of the biggest private, archaeological collections looted from various Roman sites. In this article, the authors present the iconographic features of the statuette, the religious significance of the object and through the modern story of the artefact will reflect on the biography of ancient objects once used in religious contexts.
\end{abstract}

Keywords: Artemis from Ephesus, votive small finds, bronze statuette, archaeological heritage

"But in the sanctuary of Ephesian Artemis, as you enter the building containing the pictures, there is a stone wall above the altar of Artemis called Goddess of the First Seat. Among the images that stand upon the wall is a statue of a woman at the end, a work of Rhoecus, called by the Ephesians Night" (Pausanias, Description of Greece. Translated by W. H. S. Jones and H. A. Omerod Loeb Classical Library Volumes. Cambridge, MA, Harvard University Press; London, William Heinemann Ltd. 1918). ${ }^{1}$

Ephesus became one of the most important religious centres of the Anatolian peninsula in the end of the $10^{\text {th }}$ century B.C. ${ }^{2}$ From a small, local shrine built in the Geometric age the sacralised space was maintained till 263 A.D ${ }^{3}$ surviving at least six major phases of construction, ${ }^{4}$ numerous floods and destructions ${ }^{5}$ and became one of the most successful and monumental example of maintaining a sacralised space, considered even as the "fifth wonder of ancient times". ${ }^{6}$ The success of the Artemision had multiple reasons. The advantageous geographic position between the Hellenic world and the Near East and Egypt created an economic hub in Ephesus and a local elite, who consciously used the sanctuary and the cult of Artemis from Ephesus after 356 B.C. as an important element on the growing religious market of the Mediterranean, creating various festivals, initiations in mysteries and exclusive games for the divinity. ${ }^{7}$ It was one of the eight sanctuaries in the whole Roman Empire, which legally was permitted to inherit property. ${ }^{8}$ In the early Hellenistic time, the sanctuary became already one of the major pilgrimage centres

\footnotetext{
${ }^{1}$ For a comprehensive selection of literary sources regarding the cult see: CAPODIFERRO-QUARANTA 2011, 44-55. A comprehensive bibliography on the cult and the iconography of the divinity: FLeISCHER 2009, 91, TURCSÁN-Tóth 2015, 211-231.

${ }^{2}$ On the earliest phase of the cult site see: ForstenPOINTNER et al. 2008, 33-34, Abb.12.

${ }^{3}$ Muss 2008a, 51-52.

${ }^{4}$ BAMMER 2008, 75 .

${ }^{5}$ Muss 2008b, 47-53.
}

${ }^{6}$ Antipatros from Sidon, Greek Anthology, IX.58. (The Greek Anthology in five volumes, Loeb Classical Library, translated by W. R. Paton)

${ }^{7}$ BeRnhard-Walcher 2008, 15. On the Egyptian and Phoenician relationships and economic links see: HöLBL 2008, 209 221, SeIPEL 2008, 199-209, cat. nr. 207-231. On the mysteries of Artemis Ephesia and the important economic role of the Kouretes/ bouleutai see: MCLEAN Rogers 2013, 188-189 and 399.

${ }^{8}$ FEAR 2005, 323-324. See also: Ulpian 22.6. (free translation in FEAR 2005, 324). 
and religious attractions for the Greek and later Roman elite (Fig. 1). ${ }^{9}$ It was also a place for asylum for refugees from various social classes. ${ }^{10}$

The flexible nature of the divinity, as universal mother goddess $\left(\Delta \varepsilon \sigma \pi \sigma o v \eta \mathrm{E} \phi \varepsilon \sigma \iota \alpha^{11}\right)$ created a possibility of religious syncretism and endless interpretations, reflected later also in the iconography of the mother goddesses of the Greek colonies in Anatolia (Artemis von Massalia, Artemis Leukophryne, Aphrodite from Aphrodisias, Artemis Anaitis, Artemis Sardeis, Hera from Samos, Artemis Kindyas, Artemis Astias, Eleuthera von Myra, Artemis von Perge, Artemis from Anemurium, Atargatis from Damascus, Goddess of Gabala, etc.). ${ }^{12}$ The cult image of the Great Goddess from Ephesus (Fig. 2a-b) became one of the most reproduced image of the ancient world. ${ }^{13}$ More than 80 statues and 15 reliefs are known from the Mediterranean (Fig. 3) ${ }^{14}$ found in various provinces of the Roman Empire, although only one example is known from the territory of Illyricum or Danubian provinces. ${ }^{15}$ The image of the divinity was reproduced also in small, portable forms, such as terracotta (Fig. 4) ${ }^{16}$ and plumb figurines. ${ }^{17} \mathrm{Few}$ of these small, portable examples have a precise archaeological context, all of them being produced in Asia Minor or particularly in Ephesus. ${ }^{18}$ From the currently known material it is hard to say, how much was known the image of the goddess in the "common mentality" and how the representations found outside of Asia Minor (Samos, Kyrene, Athen, Kos, Aquileia, Rome, Ostia, Verona, Liternum, Alexandria, Caesarea, Tripolis,

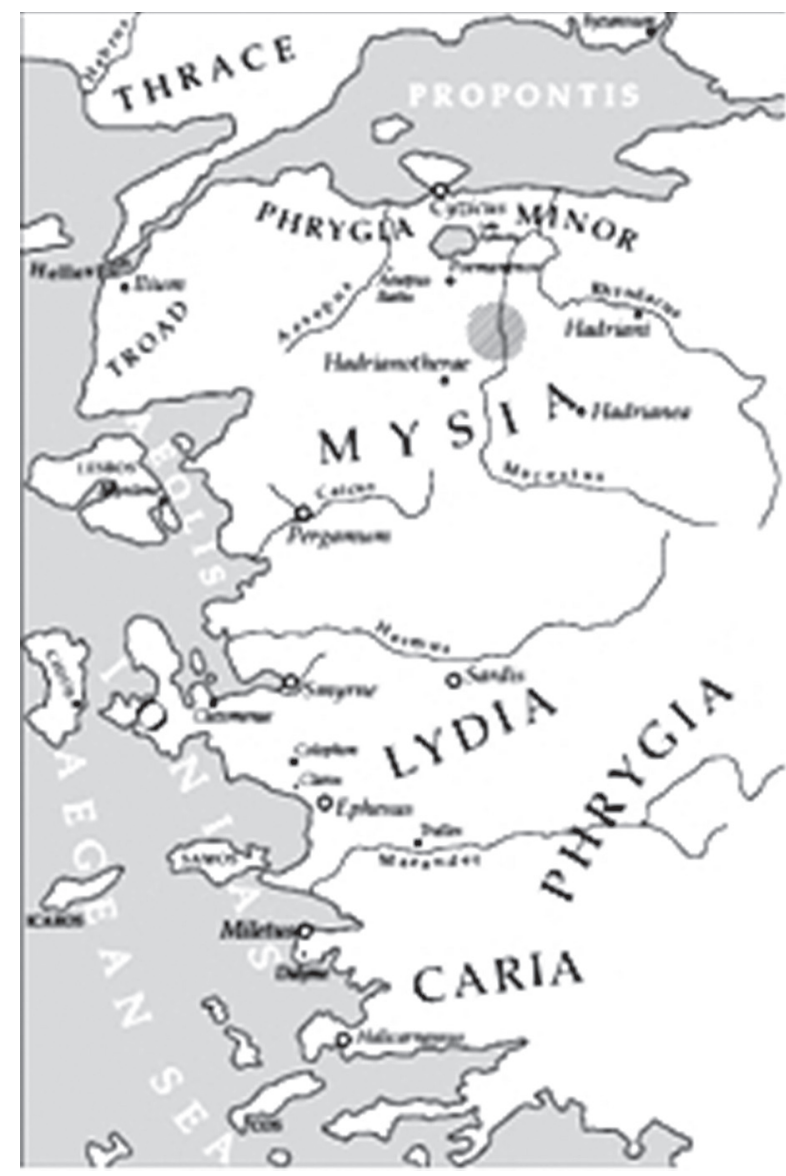

Fig. 1. Pilgrimage of Aelius Aristides (ELSNER-RUTHERFORD 2005, 277, fig. 4) Split) were spread. Pausanias explains the popularity of the divinity with her mythical origins: "But all cities worship Artemis of Ephesus, and individuals hold her in honour above all the gods. The reason, in my view, is the renown of the Amazons, who traditionally dedicated the image, also the extreme antiquity of this sanctuary. Three other points as well have contributed to her renown, the size of the temple, surpassing all buildings among men, the eminence of the city of the Ephesians and the renown of the goddess who dwells there". ${ }^{19}$

Modern scholarship explains the presence of these representations with the mobility of small groups from Asia Minor or particularly from Ephesus, interpreted as a "sacred nexus for defining identity". ${ }^{20} \mathrm{~J}$. Elsner's idea,

${ }^{9}$ Elsner-Rutherford 2005, 35; Williamson 2005, 231.

${ }^{10}$ Portefaix 1993, 197; Fleischer 2013, 259.

${ }^{11}$ FLeIsCHER 1973, 131; FLEISCHER 1984, 755.

${ }^{12}$ FLEISCHER 1973. See also: FleISCHER 1984, 756; BRODY 2007; Fleischer 2008, 25-41; CAPODIFERro-Quaranta 2011. See also: TuRCSÁN-Tóth 2006; Muss 2008b.

${ }^{13}$ FLEISCHER 1973, 130. On the reproduction of images and the role of them in the religious experience of ancient people see: GORDON 1996; EsTIENNE 2015.

${ }^{14}$ Fleischer 1973, Cat. Nr. E1-69; FleisCher 1984, 759761, Cat. Nr. 26-98b; FLEISHER 2008, 27, FLEISCHER 2009, 92, add.16. One of the latest examples discovered: CAPODIFERRO-QUARANTA 2011. See also: TuRCSÁN-TóTH 2015, 305-467 for the latest catalogue of the finds.
${ }^{15}$ FLEISCHER 1973, Cat. Nr. E-59. In Salona (Split) there was also a fragment of Hekate discovered, which indicates the presence of groups from Asia Minor: ABRAMIC 1952, 315-317.

${ }^{16}$ FLEISCHER 1984, Cat. Nr. 99-129c.

${ }^{17}$ Idem, Cat. Nr. 135a-136.

${ }^{18}$ For such examples see: Idem, Cat. Nr. 100, 111, 114, 118; Fleischer 1973, 25, Cat Nr. E-84.

${ }^{19}$ Pausanias, 4.31.8. In: Pausanias, Description of Greece. Translated by Jones, W. H. S. and Omerod, H. A. Loeb Classical Library Volumes. Cambridge, MA, Harvard University Press; London, William Heinemann Ltd. 1918.

${ }^{20}$ Steuernagel 2001, 319, 321; ElSner 2007, 251; CAPODIFERRO-QUARANTA 2011, 23, fn 33. 

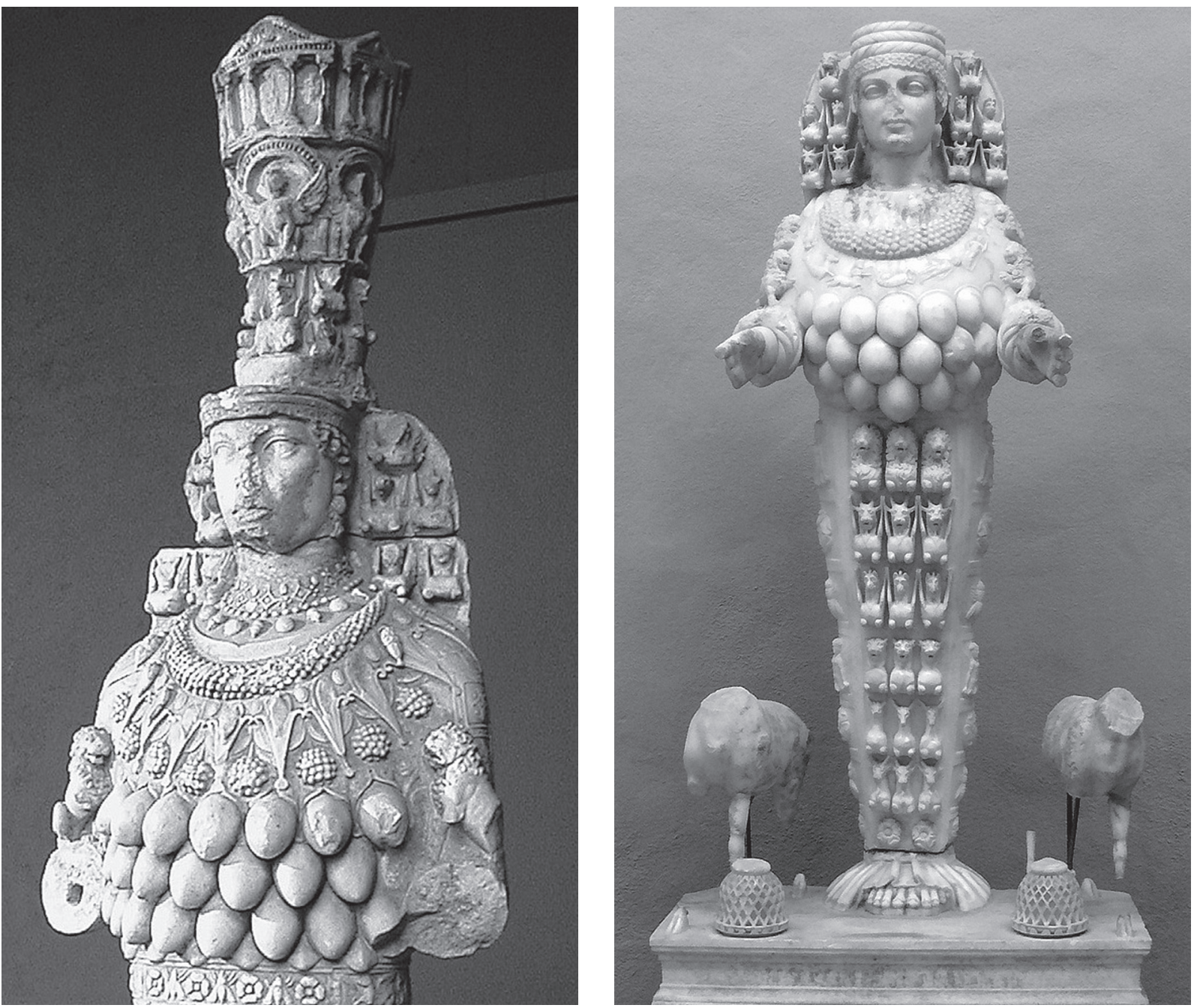

Fig. 2. a: The Great Artemis from Ephessos (wikicommons images public domain); b: The Beautiful Artemis from Ephessos (wikicommons images public domain)

that the diasporas of Microasian groups visualised their religious and ethnic identity ${ }^{21}$ through the worship of their local gods (dii patri) is well known. The wide spread of some local divinities from the Eastern provinces in the whole Empire is often related to a stubborn religious identity, as part of a "resistance" toward Roman rule and laws. ${ }^{22}$ This however, still doesn't explain how and where these numerous stone, terracotta and bronze replicas were produced. Although the presence of workshops related to the sanctuary were attested in Ephesus, ${ }^{23}$ it is uncertain, if the small portable objects - such as the bronze and terracotta statuettes - were produced locally and served as religious souvenirs or were made locally in those few places outside of Asia Minor where the cult is attested. One of the most important sources on the work of metal workshops and religious souvenirs from Ephesus was reported by the Apostle Paul himself in the Acts of the Apostles (Acts 19, 23-28). ${ }^{24}$

${ }^{21}$ ELSNER 2007, 229-231. On the visibility of religions, see: BEARD-NORTH-PRICE 1998, 260-278.

${ }^{22}$ SCHÄFER 2004. For a different idea, see: PISO et al. 2011. On Roman identities see: MatTingly 2014, 35-59.

${ }^{23}$ MacLean-Rogers 2013, 399.

24 "About that time there arose a great disturbance about the Way. A silversmith named Demetrius, who made silver shrines of
Artemis, brought in a lot of business for the craftsmen there. He called them together, along with the workers in related trades, and said: "You know, my friends, that we receive a good income from this business. And you see and hear how this fellow Paul has convinced and led astray large numbers of people here in Ephesus and in practically the whole province of Asia. He says that gods made by human hands are no gods at all. There is danger not only that our trade will lose its good 
The presence of the small sized and portable terracotta and bronze statuettes proves that the divinity was worshipped not only in large sanctuaries or shared spaces, but also in domestic, private contexts.

From the settlements of Apulum we know recently at least 15 bronze statuettes, ${ }^{25}$ more than from any other Roman cities from the provinces of Dacia. Some of them, such as the famous Apollo and Fortuna statuettes now in

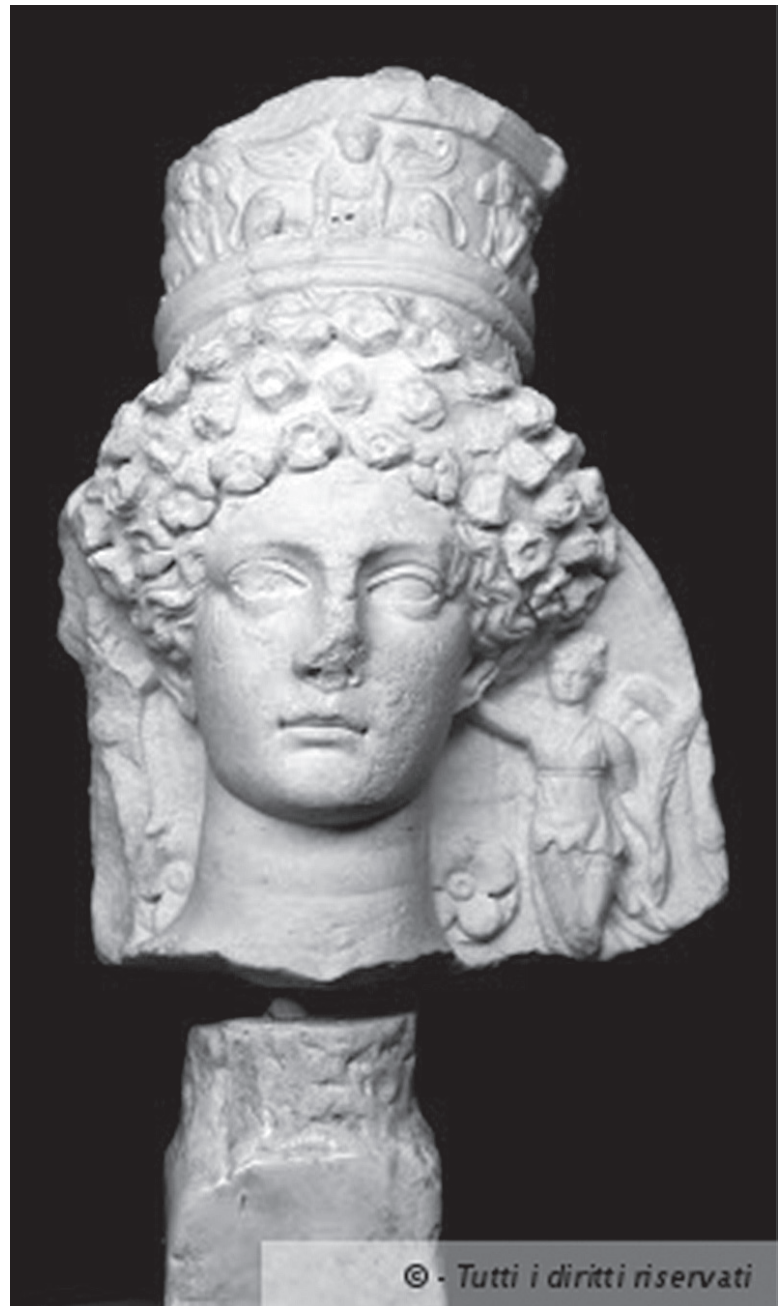

Fig. 3. Artemis Ephesia from Rome (Via Marmorata. Photo: Public domain. http://www.archeoroma.beniculturali.it/sites/ default/files/imagecache/grande/images/Artemide.jpg. Last accessed: 23.04.2016.)

name, but also that the temple of the great goddess Artemis will be discredited; and the goddess herself, who is worshiped throughout the province of Asia and the world, will be robbed of her divine majesty". Trans. NIV (New International Version 2011).

${ }^{25}$ PoP 1990-1993, 223-226; TुEPOSU-MARINESCU-PoP 2000, 38-39, no. 20, Pl. 14, 44-45, no. 43, Pl. 24, 56, no. 46, Pl. 26 , 85 , no. 90,93 , no. 105 , Pl. 56,105 , no. 126 , Pl. 65 , 128 , no. 171 , Pl.

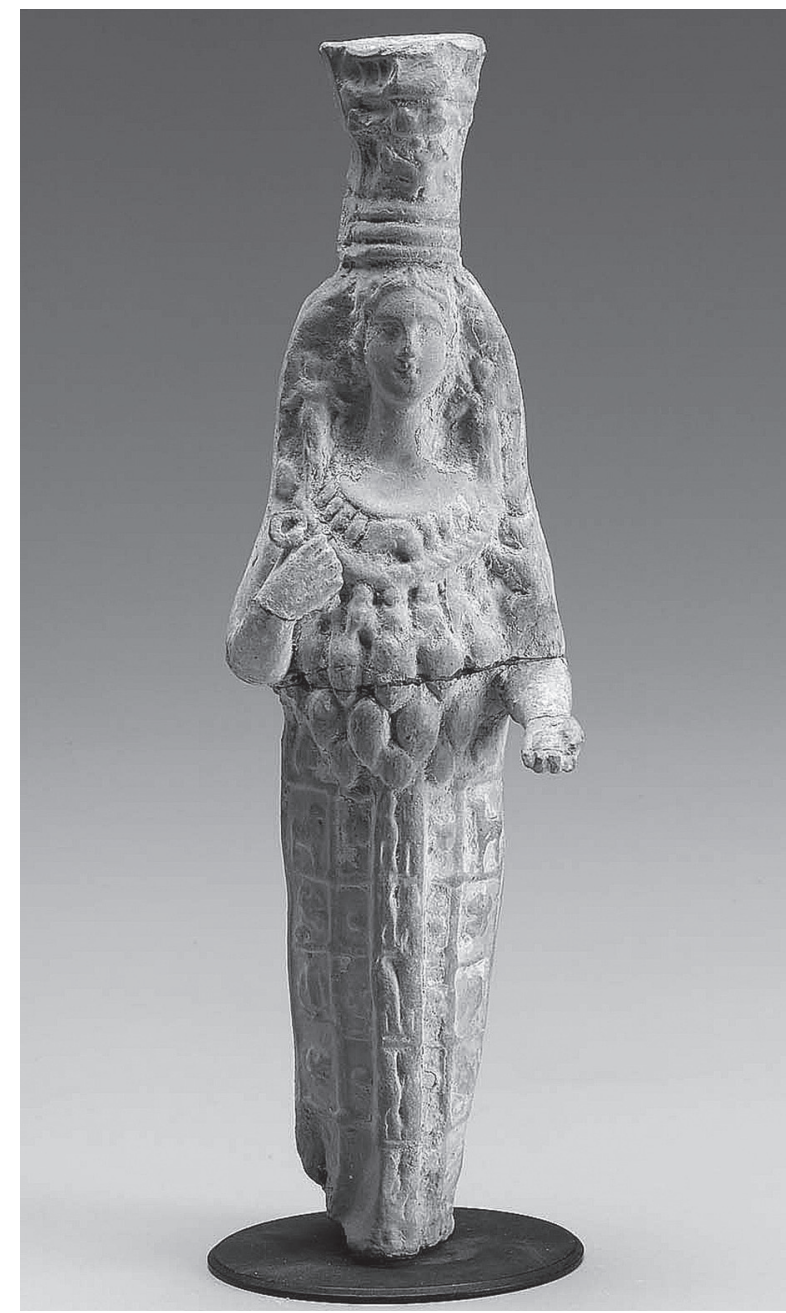

Fig. 4. Terracotta statuette of Artemis Ephesia (Museum of Fine Arts, Boston, cat. nr.03.886a. Photo: public domain. http://mfas3.s3. amazonaws.com/objects/SC53219.jpg. Last accessed: 23.04.2016.)

79, 137-138, no. 206, Pl. 82, 141, no. 215, Pl. 87; In the last years, numerous new statuettes were discovered. See also: Moga 2004, 253-258, Fig. 1a-c; Ота 2012, 104, Pl. XXIX,4; OтA-Bolog 2016 (in press). The statuette of Sol Invictus presented by Wiegels is probably identical with the one published by E. Zefleanu: ZeFLEANU 1949, 170-171; WIEGELS 2013, 1-5. 

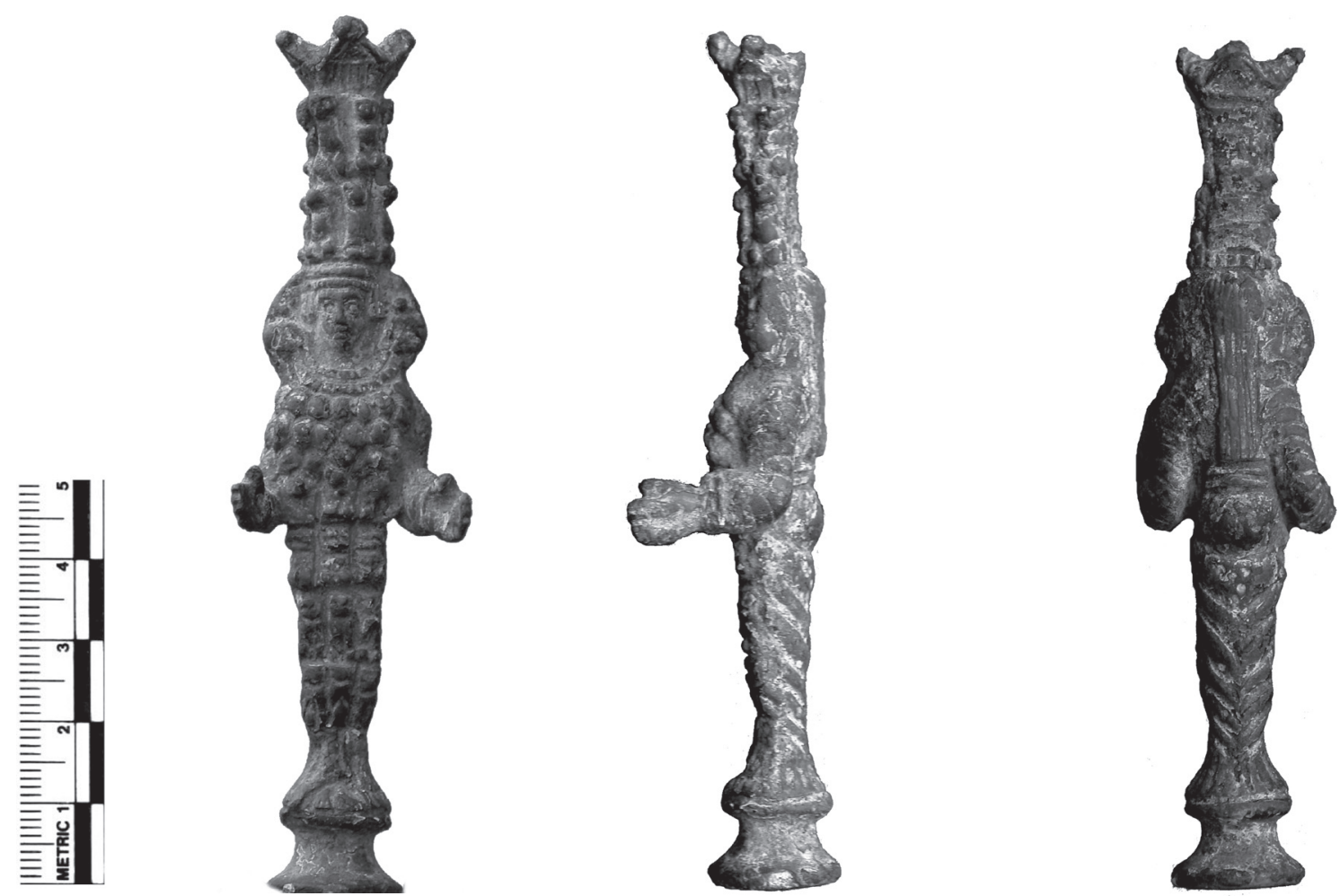

Fig. 5. a: Statuette of Artemis Ephesia from Apulum. Frontal view (Photo: National Museum of Union, Alba Iulia); b: Statuette of Artemis Ephesia from Apulum. Lateral view (Photo: National Museum of Union, Alba Iulia)

c: Statuette of Artemis Ephesia from Apulum. Back-view (Photo: National Museum of Union, Alba Iulia)

the Kunsthistorisches Museum are masterpieces of Italian workshops and reflect the possibilities and economic status of the local elite. ${ }^{26}$

The bronze statuette of Artemis Ephesia from Apulum (Fig. 5a-c) was made by direct bronze casting using clay moulds. With a $104 \mathrm{~mm}$ height and $15 \mathrm{~mm}$ wide at the pedestal, the statuette follows the same dimensions attested in the preserved analogies of similar bronze statuettes of the divinity. It is fully and well preserved, with traces of green patina. Some of the figures on the polos and on the main registers of the body are schematically preserved and hard to identify. Only the tympanon on the polos and the bees in the lower register can be identified with certainty. The arms of the goddess are outstretched the fists are closed and wears a short tunic with long sleeves. On the wrist seems to wear flax threads or similar textiles, which can be an allusion to the protective role of the asylum seekers, who arrived with similar threads to the sanctuary. ${ }^{27}$

The statuette from Apulum is the seventh known, authentic bronze representation of the divinity and the fifth one which exist today. ${ }^{28}$ After it was recuperated in the spring of 2006, alongside other artefacts from Roman period, was published two years later by V. Moga. ${ }^{29}$ Based on "the physiognomy, decoration of the vestment, crown and majestic attitude" of the divinity, Moga identified wrongly the goddess with Hekate "or another divinity which suggest a syncretism". ${ }^{30}$ His hypothesis was based on the fact, that the cult of Hekate Triformis is attested in Roman Dacia by numerous statues and reliefs. ${ }^{31}$ Although the cult of Hekate was present in Ephesus and it's often appears together with Artemis Ephesia in magical contexts, ${ }^{32}$ her iconography (especially the polos and the classical Greek

\footnotetext{
${ }^{26}$ DiACONESCU 2014.

${ }^{27}$ MACLEAN Rogers 2013, 182

${ }^{28}$ FleisCher 1973, 25-27, Cat. Nr. E82-E87, TuRCSÁN-
} TóTH 2015, 410-416, Cat. Nr. G1-G7. It's important to mention that G5 in her catalogue is not a statuette but a bronze plate figurine. There is also a silver statuette fragment from Münster: FLEISCHER 2009, 92 , add.5. For modern forgeries, see: THIERSCH 1935, 87, Taf. LVI. 3-4.
${ }^{29}$ Moga 2008, 83-84, no. 1, Fig. 1.

${ }^{30}$ Ibidem, 84.

${ }^{31}$ Most famous is the statue of Hekate Triformis found probably in Salinae. For a complete bibliography and the latest publication of this statue, interpreted as a Hekataion, see: CARBONI 2015, 147-149. R. Fleischer enrolled the Hekataion in his work on Artemis Ephesia and other mother goddesses from Asia Minor in a category 
vestment) is significantly differs from the canonical iconography of the Great Mother from Ephesus. ${ }^{33}$

The iconography of the Great Mother from Ephesus has more than a thousand years long evolution from a wooden xoanon $^{34}$ till the latest, so called canonical representation of the divinity (the Great Artemis from Ephesus, The beautiful Artemis from Ephesus and the Small Artemis from Ephesus) reproduced in numerous copies from the end of the Trajanic era and especially in the Antonine period..$^{35}$ With the exception of the Boston and Bologna statuettes representing Artemis with the shroud or hood (Figs 6-7), ${ }^{36}$ the examples from Istanbul (Fig. 8) and Paris (Fig. 9a-b) are following the iconographic canon established in the Hadrianic period by the two main cult images, the "Beautiful Artemis" and the "Great Artemis" (Fig. 2a-b). ${ }^{37}$ The statuette from Istanbul is the only one known from Ephesus discovered before $1905 .^{38}$ The example from Paris is the closest analogy for our piece: the exaggerated size of the polos crowned with the tympanum and tetrapylon temple, the close and strong arms showing toward the viewer, the emphasized nimbus around her neck, the quadratic face, decorated with heavy jewellery the emergent and dominant "breasts" and the schematised four panels with the fifth, representing the bubbled foot of the divinity are common features, following the canonical representation of the Great Artemis from Ephesus. However, there are few particularities in the statuette from Apulum, which makes a more accurate copy of the Great Artemis than the statuette from Paris and need to be discussed in details.

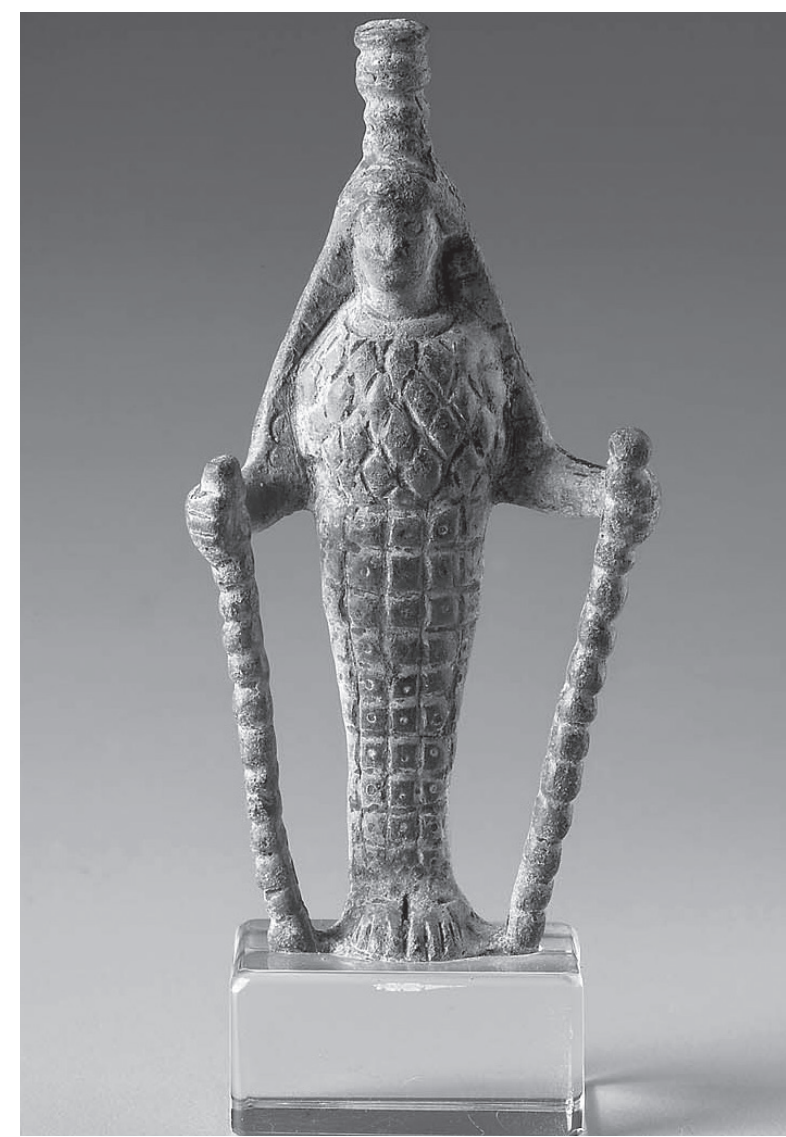

Fig. 6. Bronze statuette of Artemis Ephesia from Asia Minor (Museum of Fine Arts, Boston, cat. nr. 66.951.)

The polos of the canonical Great Artemis ${ }^{39}$ - copied in various forms also by some provincial examples ${ }^{40}$ - is divided in three registers: the upper one is an architectural form with a tetrapylon and tympanum decorated

called ,,andere Göttinen” suggesting the iconographic similarities and influences of the Ephesian mother goddess on other divinities of the region: FLEISCHER 1973, 284-287. A. Diaconescu and A. Schäfer presumed that the statue originally came from Apulum. Similar idea was raised already by A. Popa in 1975. See also: Popa 1975; DiACONESCU 2014, 84-95; SCHÄFER 2004. Carboni's catalogue mentions only 3 examples in Dacia (II.12.8, II.12.9, tav. XXXI.3, XXXI.4, XXX 8ab). Other pieces, such as the famous statue from Sarmizegetusa (lupa 17663) or the relief from Sibiu (lupa 17496), the representation from Drobeta, Mehadia are not enrolled in her repertory. See also: ȘTEFĂNESCU 2003, 131-140, BoDA-SZABÓ 2014, 85-86. For the problematic aspect of Hekate, as chtonian divinity: NEMETI 2012, 182-183.

${ }^{32}$ CARBoni 2015, 107-109. About Artemis Ephesia and Hekate see: ARNOLD 1989, 23-24. On the syncretism of Artemis and Hekate, named as Ditagoie, see: CARBONI 2015, 35-40. For a different point of view see: STRELAN 1996, 84.

${ }^{33}$ On the iconography of Hekate, see: SARIAN 1992, 9851018, Taf. 654-673; GoCEVA 1992, 1018-1019; SiMON 2009, 238. In almost all of the cases, Hekate has a simple polos, representing a tower or city wall, doors or gates and it is represented with long hair and classical Greek vestment. In some cases, Artemis rom Ephesus appears with similar, simplified polos, but never with a classical Greek vestment: FLEISCHER 1973, Taf. 40.

${ }^{34}$ Muss 2008b, 63-64.

${ }^{35}$ FleisCher 2008, 32.

${ }^{36}$ THIERSCH 1935, Taf. XXXIX,3; FLeISCHER 1973, E-83. The statuette was not dated by the publisher. Some of the early representations of the divinity on coins (FLEISCHER 1973, Tafeln 53b-57a, 74a-b, 75a-c; FLeISCHER 2008, 31, Abb. 9) form the Claudian period shows similar iconography as the statuette from Boston. It is hard to say, if these early representations had a real statue as model or conventional representations. The earliest statuary representation is the Basel statue dated around 100 B.C (FleISCHER 2008, 28, Abb. 7). Unfortunately, the arms of the statue are missing, which could help us to reconstruct the first model which served as analogy of the coin representations and the Boston statuette. The representation of this type, the perianth headed divinity often represented on coins (FLEISCHER 1973, Taf. 75c) could be related to a certain festival or a moment of the mystery cult, when the statue was decorated and covered with textiles.
${ }^{37}$ FLEISCHER 1973, 46.
${ }^{38}$ Ibidem, 25-26.
${ }^{39}$ Ibidem, Taf. 16 


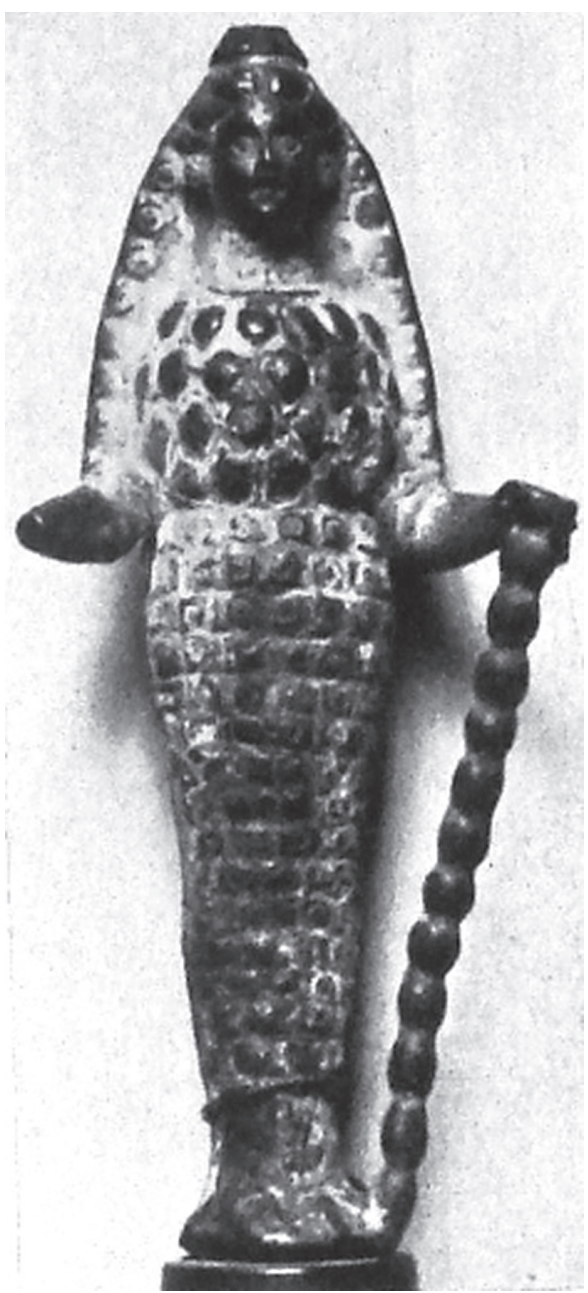

Fig. 7. Bronze statuette of Artemis Ephesia (Bologna, Museo Civico, cat. nr. 854. Photo: ThIERsch 1935, Taf. XXXIX nr. 13)

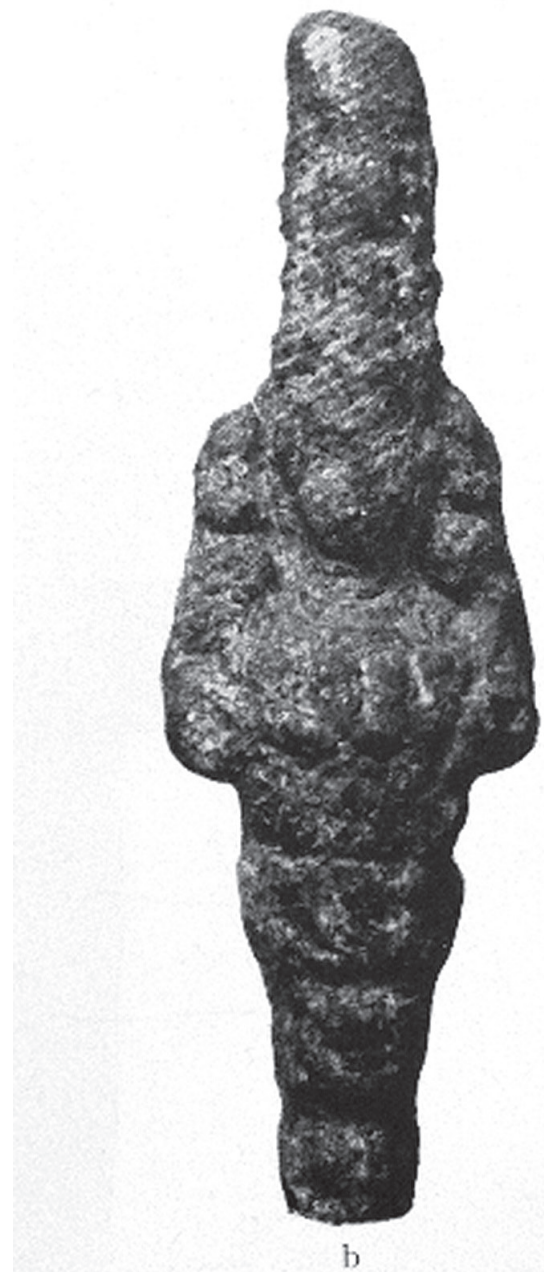

Fig. 8. Bronze statuette of Artemis Ephesia (Istanbul, Arkeoloji Müzesi, cat. nr. 2529. Photo: FLEISCHER 1973, taf. 43b)

inside with a circular motive, which appears again, schematically and oversized in our case. ${ }^{41}$ The building was interpreted as the new neokorinthian form of the Artemision after 129 A.D. in Hadrian's time although it's functionality it could be related more with the city-goddess (Tyche) role of Artemis from Ephesus. ${ }^{42}$ In the case of the Apulum statuette however, the building - represented in an exaggerated size - has an acroterion on the tympanum, ${ }^{43}$ which suggest, that Knibbe's idea could be plausible. ${ }^{44}$ Similarly to the majority of the post-Hadrianic representations, the aedicula appears three times in different angles and directions as a four column type building, not represented however on the backside of the statuette. ${ }^{45}$

The second register of the polos on the Great Artemis of Ephesus, represents winged sphinxes or griffons under an arch. ${ }^{46}$ This register however varies in other known cases. ${ }^{47}$ In our case, the griffons or panthers are represented in a very schematic form and are badly preserved.

${ }^{40}$ Hermary 2009, 136-139; CAPOdifERro-Quaranta 2011, 16-17.

${ }^{41}$ For the circular motive - probably the symbol of the Moon - see: FLEISCHER 1973, Taf. 55b.

${ }^{42}$ FLEISCHER 2009, 96 contesting Knibbe's theorie.
${ }^{43}$ BÜYÜKKOLANCI-ZHUBER-OKROG 2008, 93-103; MuRPHY-O'CONNOR 2008, 119 citing Pliny the Elder's description on the Artemision: NatHist 36.21. 95-97.

${ }^{44}$ KNIBBE 1995, 96-99. See also: FleisCHER 1973, 51-58.

45 TurcsáN-Tóth 2015, 90-92.

${ }^{46}$ These mythical animals - probably as Persian influences - appears also in various forms as bronze decorations found in the 

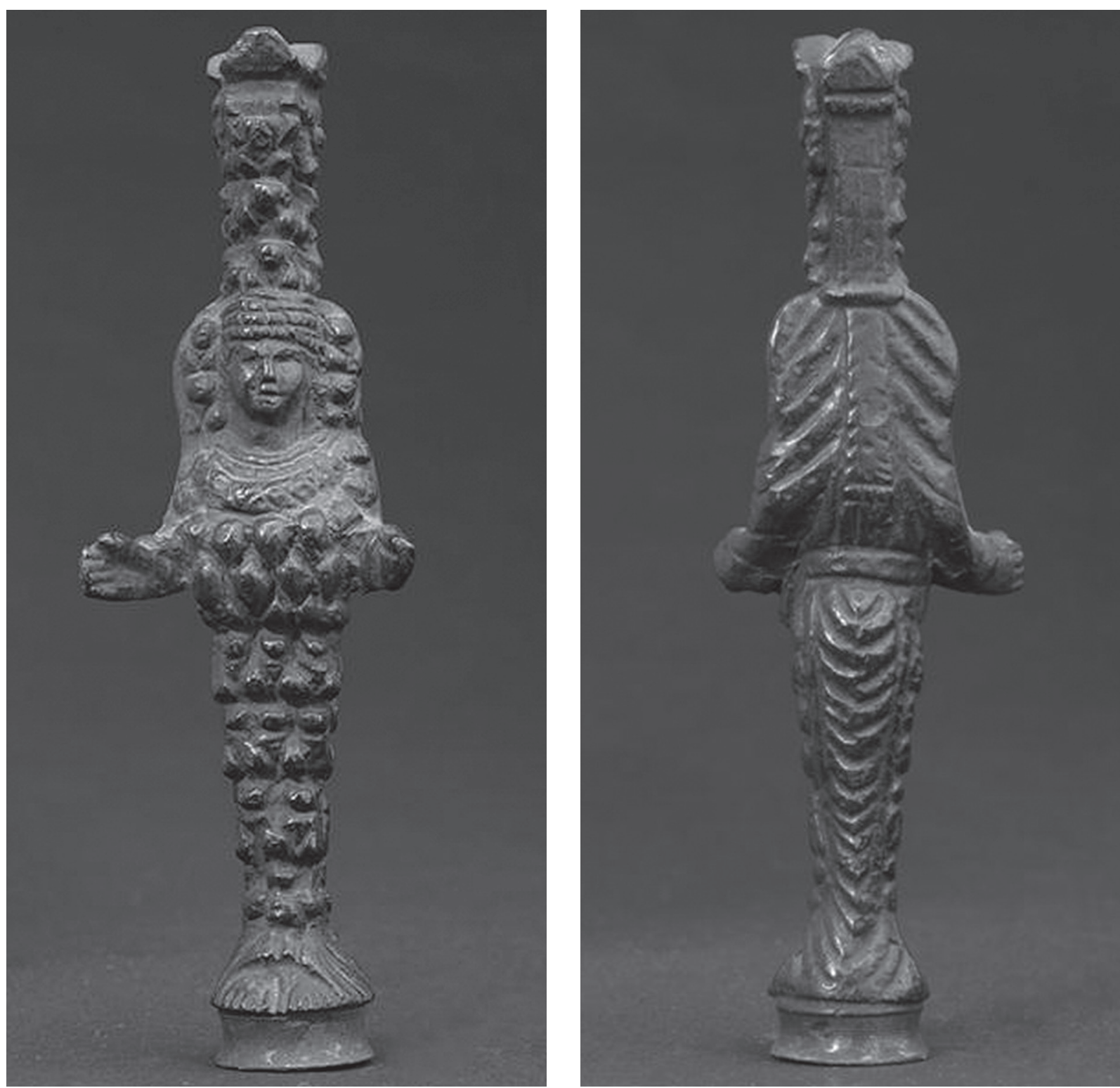

Fig. 9. a: Bronze statuette of Artemis Ephesia, frontal view (Paris, Louvre, cat. nr.: E22241.

Photo: http://bit.ly/1IgKcfp. Last accessed: 23.04.2016.); b: Bronze statuette of Artemis Ephesia, back-view (Paris, Louvre, cat. nr.: E22241.

Photo: http://bit.ly/1IgKcfp. Last accessed: 23.04.2016.)

The head of the divinity is decorated with a crown or head-gear with two pendants on both sides. A veil, having the shape of a nimbus, covers the head. ${ }^{48}$ The goddess is also wearing a double necklace. This jewellery, although became a schematized and often copied one, reflects the archaic metallurgy and jewellery types identified also in the earliest treasures of the sanctuary. The inferior part of the statuette is divided in numerous registers, three of them being visible and more elaborated, the forth one beyond the torso is badly preserved. The zoomorphic figures are schematically represented on the interior part of the body, hard to identify their nature. The statuette, following the main iconographic features of the Great Artemis from Ephesus, could have been decorated with grif-

recent excavations from the sanctuary: SEIPEL 2008, 211-212; FREYER-GRIGGS 2013.
${ }^{47}$ HeRMARY 2009, 136-139.

${ }^{48}$ FLEISCHER 1973, 58-61; TuRCSÁN-TÓTH 2015, 100-103. 
fons, panthers, bulls and bees, although none of them are clearly visible. A particular importance is the association of bees with the cult of Artemis from Ephesus and other goddesses from Asia Minor. After some opinions, it symbolizes the eternal life and purity and together with the testicles of the bulls (or the breasts) it was associated also with the mysteries of Artemis Ephesia. ${ }^{49}$ After Porphyry, souls were conceived of as coming down from the Moon goddess Artemis in form of bees and honey was symbol of death and resurrection. Souls who lived pure life are called Melissae, similarly to some of the priestesses of Artemis and Demeter-Kore in Hellenic world. ${ }^{50}$

The goddess wears a long skirt, leaving visible the foot. The authentic Roman pedestal of the statuette following the shape of a column base, a common shape for small size bronzes, found also on other exported statuettes from Dacia. ${ }^{51}$ The back of the statuette is schematically worked, presenting the cloths and folds, in almost identical style as we can observe on the analogy from Paris.

The exact provenience of the artefact is uncertain. After the oral confirmation of the collector, he found the statuette in the central area of the Partoş (80$90 \mathrm{~m}$ North from the intersection between Str. Dacilor and Reg. V. Vănători), the territory of the Colonia Aurelia Apulensis, where numerous bronze statuettes among them, probably the famous Apollo from Vienna - was found too (Fig. 10). ${ }^{52}$

The civil settlement was well known for its various groups from Asia Minor attested through epigraphic sources. A particular inscription (IDR III/5, 62) dedicated to Diana Mellifica sacrum (the honey maker Diana) long associated with indigenous Dacian religion $^{53}$ is in fact, a direct evidence for the cult of a certain Artemis from Asia Minor or Greece. ${ }^{54}$ Associated with the above mentioned, honey maker bees and bears (for

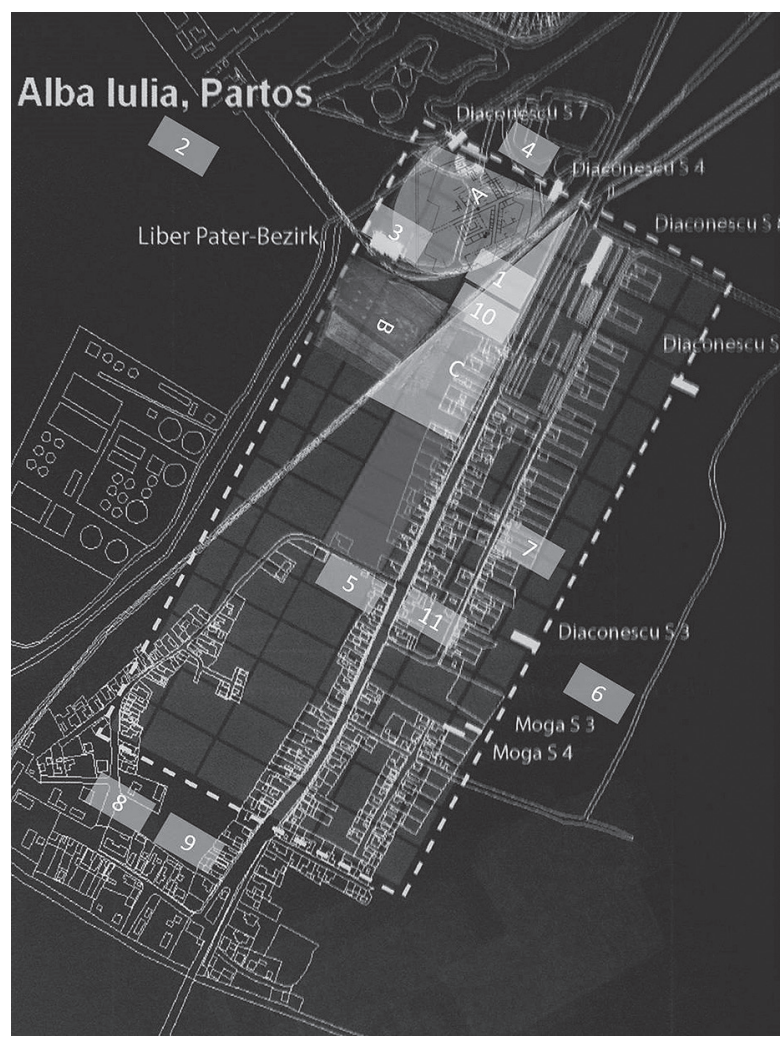

Fig. 10. Map of Colonia Aurelia Apulensis with the main researched areas. The darker area marks the territory, where the statuette was probably found. Legend: A: geophysical survey of the Apulum Project from 2003; B: aerial photograph of the Apulum Project by W. Hanson and I. Oltean; C: area examined by K. Gooss in 1867 and excavated by Cserni. Nr. 1: the big house excavated in 1911;

Nr. 2: Roman spring and possible shrine of Silvanus; Nr. 3: Liber Pater shrine; Nr. 4: Asclepieion or the so called "Locus Apulensis"; Nr. 5: Roman Forum, findspot of the Hercules Apulensis; Nr. 6: Deus Aeternus shrine; Nr. 7: house with mosaic representing the winds; Nr. 8: possible Mithraeum of Károly Pap; Nr. 9: possible Iseum; Nr. 10: temple of Jupiter described by K. Gooss;

Nr. 11: temple ruin in the garden of Gligor Sas (Photo: Szabó 2016, 139. fig. 113) example, Artemis Brauronia), ${ }^{55}$ the presence of Diana Mellifica in Apulum can be related to the wide spread cult of various female divinities with similar attributes among the Greek speaking groups arrived in Dacia. ${ }^{56}$

\footnotetext{
${ }^{49}$ FeRRARI 2003, 51.

${ }^{50}$ RANSOME 2004, 107.

${ }^{51}$ See the statuette of Jupiter from Potaissa: BĂRBULESCU 1984, 100, pl. XI.

${ }_{52}$ On the terrritory see: SZABÓ 2016, 123-140.

${ }^{53}$ Bodor 1989. See also: Nemeti 2013.
}

\footnotetext{
${ }^{54}$ The dedicant, Comatius Super is known from several inscriptions from Colonia Aurelia Apulensis, where he played a key role in the Liber Pater shrine and the group from Asia Minor.

${ }^{55}$ CARABia 1982, Fischer-HANSEN-Poulsen 2009, 334 335, DOWDEN 2010, 51-52.

${ }^{56}$ The cult of Diana Mellifica in this context is strictly related to the important role of honey in wine consumption within the sanctuary of Liber Pater from Apulum.
} 


\section{WAY OF AN OBJECT: FROM THE BLACK MARKET TILL THE MUSEUM}

Since Kopytoff's seminal work on the cultural biography of things, studies focusing on the life circle of objects within the study of materiality emphasize the various role and transforming identity of objects, as their owner, functionality and contextual use changed through time, ${ }^{57}$ Although, the statuette of Artemis after the $3^{\text {rd }}$ century A.D. lost its identity as a transporter and agent of religious devotion and ethnic identity, it preserved its value, as artefact, due to its material, artistic elaboration and relative rarity. In this sense, the statuette - on the black market or later, in the museum - continues to be an indirect agent of Roman culture and identity, but without the personal-individual memory of religious experience.

Our object was recuperated in an unusual way, not as it should happen with an artefact, which is part of the archaeological heritage. After operative information, in March, 2006 in the home and working office of a citizen of Alba Iulia the police effectuated an official perquisition. Based on external sources, the individual owned a gold coin from the so called Târsa-Luncani hoard, found actually in the Orăştiei Mountains, near the Dacian capital, Sarmizegetusa Regia. The unnamed individual had two impressive archaeological collections in his office and in his house, containing numerous types of small finds (coins, fibulae, terracotta objects, glass fragments, bronze statuettes, worked bone objects, fresco fragments, tegulae etc. - Fig. 11) and Roman stone material too (epigraphic altars, funerary and votive column-fragments, statue-heads, stone blocks, grindstone, etc.). ${ }^{58}$ The majority of the rediscovered objects are from Roman period, although numerous pieces came from prehistoric, Dacian or Medieval periods and from various sites. Consulting the phone agenda of the dealer revealed that he was in touch with the most notorious persons of the local and Romanian black market. The pieces - among them many discovered in situ in various prehistoric, Roman and early medieval layers - were bought from a certain group of people, known as a high elite of the black market trade in local context. Some of the objects collected between 1991 and 2006 had also removed inventory numbers, which suggest the implication of local archaeologists in the trade of these artefacts. The collector affirmed, that the wide spread phenomena of trading with ancient artefacts had numerous reasons in

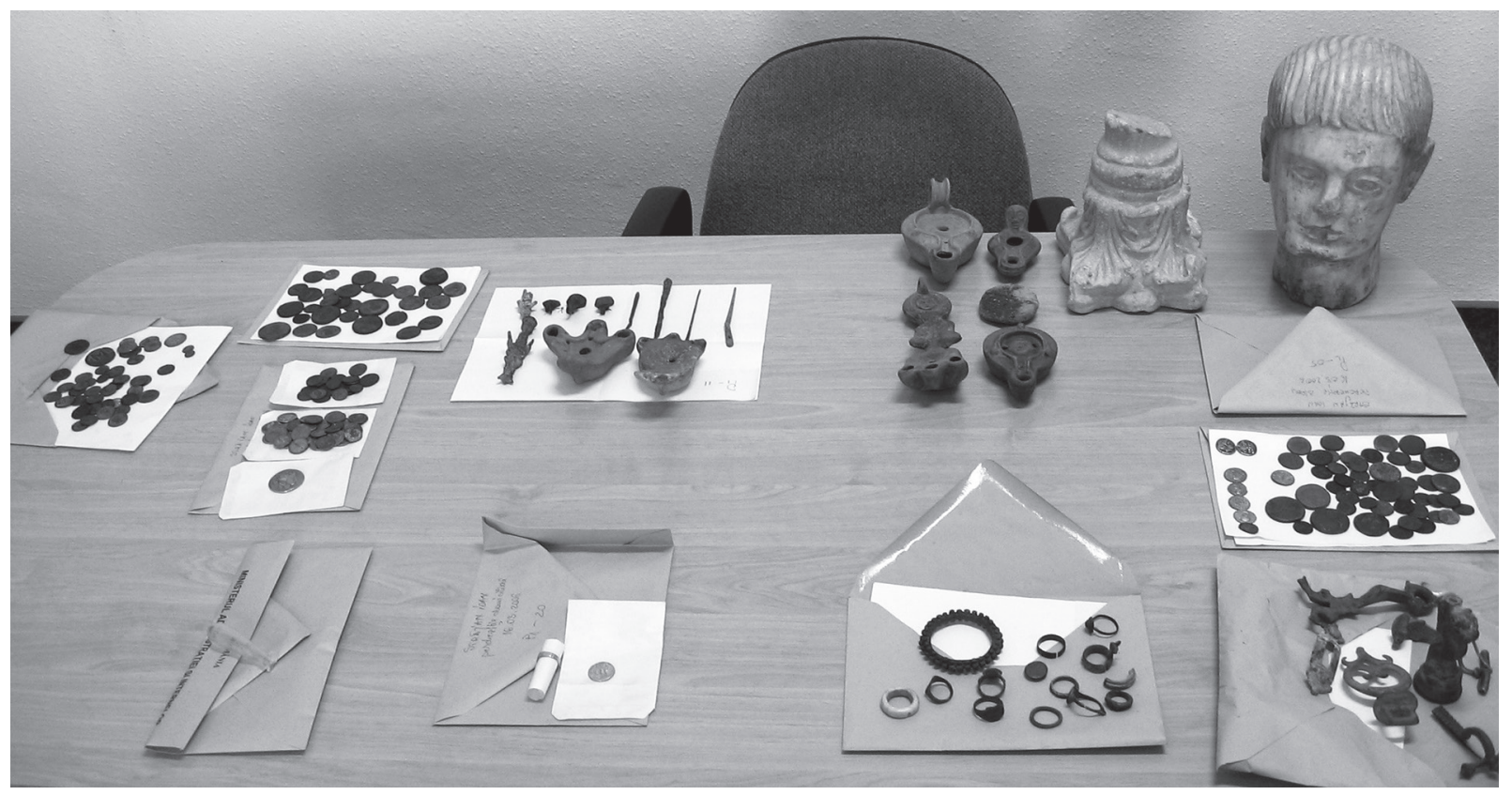

Fig. 11. Artefacts rediscovered by local authorities in Alba Iulia (Photo: Marius Mihai Ciută)

${ }^{57}$ HAHN-WEISS 2013.
${ }^{58}$ The small finds were inmediately recuperated by the police and transfered to the costudy of the National Museum of Union from Alba Iulia. The larger items will remain in custody till the end of the juridical process. 
the early 1990's: beyond the fact, that Romania had several problems in protecting the archaeological heritage by new laws, ${ }^{59}$ the local elite - together with some regrettable archaeologists - thought, that these valuable artefacts will be better protected in private collections, than to be sold abroad. Their attitude - although legally is unacceptable - gave a new identity and a continuity for the life circle of the object. The statuette continued to be a piece of art and a memory of the sacred, although without a personal attachment. The "patriotic" attitude of the traders created another type of identity and a new chapter in the long biography of this object.

Since 2006, the bronze statuette lies unnoticed in the tresory of the National Museum of Union, Alba Iulia. If it will be presented once for the large public, a new chapter will begin in his life, as object: that of the admired, museal artefact.

\section{CONCLUSIONS}

The bronze statuette of the Great Mother from Ephesus found in Apulum is one of the few remained representations of the divinity in small, portable forms. Probably an imported artefact, it belonged to a worshiper, who had a very strong - ethnic, religious or both kind of bond - with the divinity from Asia Minor. As an agent for a religious act (possibly a pilgrimage) of the individual, the statuette played an important role in the maintenance of the memory of a highly individual, religious experience and contributed also to the long term success of the great sanctuary of Artemis Ephesia. As a product and souvenir of a large scale religious market, the material and elaborated work of the statuette represented a modest, but significant value for its owner, who had a strong bond with it. After a long period of discontinuity in the life circle of the object, the statuette gained a new identity, that of an artefact on the black market and later, museal object. The case study of this statuette shows not only the relativity of object-biographies and the constant change of object-identities, but reflects the rich religious networks of Apulum, one of the richest urban centres of the Danubian provinces.

\section{REFERENCES}

ABRAMIC 1952

ARNOLD 1989

BAMMER 2008

BĂRBULESCU 1984

BEARD-NORTH-PRICE 1998

BERNHARD-WALCHER 2008

BoDA-SzABÓ 2014

BORȘ 2014

BRODY 2007

CAPODIFERRO-QUARANTA 2011

CARABIA 1982

CARBONI 2015
BODOR 1989

BÜYÜKKOLANCI-ZHUBER-OKROG 2008

= M. ABRAmIC: Antike Kopien griechischer Skulpturen in Dalmatien. In: Festschrift für Robert Egger. Beiträge zur älteren europäischen Kulturgeschichte. Hrsg.: M. Gotbert. Klagenfurt 1952, 303-326.

= C. Arnold: Ephesians: Power and Magic. The Concept of Power in Ephesians in Light of its Historial Setting. Cambridge 1989.

= A. BAMMER: Zur Geographie des Artemisheiligtums. In: Die Archäologie der ephesischen Artemis. Gestalt und Ritual eines Heiligtums. Hrsg.: U. Muss. Wien 2008, 17-21.

= M. BĂRBULESCU: Interferențe spirituale în Dacia romană [Spiritual Interferences in Roman Dacia]. Cluj-Napoca 1984.

= M. BEARD-J. NorTh-S. Price: Religions of Rome. Cambridge 1998.

= A. BERnHARD-WALCHER: Das Heiligtum der Artemis von Ephesos - ein verschollenes Weltwunder. In: SEIPEL 2008, 15-25.

= I. BoDA-Cs. SzABÓ: The Bibliography of Roman Religion in Dacia. Cluj-Napoca 2014.

= A. BODOR: Die griechisch-römischen Kulte in der Provinz Dacia und das Nachwirken einheimischer Traditionen. In: ANRW II.18.2. Berlin-NewYork 1989, 1077-1164

= C. I. BoRș: Protejarea patrimoniului arheologic din România. Despre situri şi monumente arheologice din perspectiva evoluției cadrului legislativ în context European. Cluj-Napoca 2014.

= L. Brody: The Aphrodite of Aphrodisias. Mainz 2007.

= M. BÜYÜKKOLANCI-K. ZhUBER-OKROG: Architektur eines Weltwunders. In: SEIPEL 2008, 93-106.

= A. CAPODIFERro-P. QuARANTA: Gli scavi di via marmorata. 2: Alle pendici dell'Aventino. Milano 2011.

= J. CARABIA: Diana Mellifica. Pallas. Revue d'étude antique 29 (1982) 57-65.

$=$ R. CARBONI: Dea in limine. Culto, immagine e sincretismi di Ecate nel mondo greco e microasiatico. Raden/Westf. 2015.

${ }^{59}$ For the legal background of the archaeological heritage of Romania see: BoRș 2014. For the case study of Apulum: CIUTĂ 2013; CIUTĂ 2014 . 
CIUTĂ 2013

CIUTĂ 2014

DiACONESCU 2014

DOWDEN 2010

ELSNER 2007

ELSNER-RUTHERFORD 2005

ESTIENNE 2015

FEAR 2005

FERRARI 2003

FisCHER-HANSEN-POULSEN 2009

FLEISCHER 1973

FLEISCHER 1984

FLEISCHER 2008

FLEISCHER 2009

FLEISCHER 2013

FORSTENPOINTNER et al. 2008

FRAYER-GRIGGS 2013

GoCEVA 1992

GORDON 1996

HAHN-WEISS 2013

HERMARY 2009

HÖLBL 2008

KNIBBE 1995

MatTingLy 2014

MCLeAn Rogers 2013

Moga 2004

Moga 2008

Murphy-O'ConNor 2008 Muss 2008a

Muss 2008b
= M. CIUTĂ: Recovering the past. The case of Hercules Apulensis. Acta Terrae Septemcastrensis 12 (2013) 65-74.

= M. CIUTĂ: Istoria pierdută - istoria recuperată. Cazul Hercules 2013 (Lost history recovered - the case of Hercules from 2013). Apulum 51 (2014) 471-490.

= A. DiACONESCU: Statuaria majoră în Dacia romană. I/1: Statua cum base sua. Tipologia, cronologia şi funcţionalitatea statuilor onorifice şi funerare [Statues in Roman Dacia I. Statua cum base sua. Typology, chronology and functionality of honorary and funeral statues]. Cluj-Napoca 2014.

= K. Dowden: Olympian gods, Olympian Pantheon. In: A Companion to Greek Religion. Ed. : D. Ogden. New York 2010, 41-56.

= J. ELSNER: Roman Eyes: Visuality and Subjectivity in Art and Text. Priceton 2007.

$=$ J. ELSNER-I. RUTHERFORD (eds): Pilgrimage in Graeco-Roman and Early Christian Antiquity. Seeing the Gods. Oxford 2005.

$=$ S. EstiEnNE: Images. In: A Companion to the Archaeology of Religion in the Ancient World. Eds:

R. Rüpke, R. Raja. Blackwell companions to the ancient world. Chichester 2015, 379-387.

= A. FEAR: A journey to the end of the World. In: ELSNER-RUTHERFORD 2005, 319-332.

= A. FERRARI: Dicţionar de mitologie greacǎ şi romană (Dictionary of Graeco-Roman mythology). Bucureşti-Iaşi 2003.

$=$ T. Fischer-Hansen-B. Poulsen: From Artemis to Diana: The Goddess of Man and Beast. Acta Hyperborea 12. Copenhagen 2009.

$=$ R. FLEISCHER: Artemis von Ephesos und verwandte Kultstatuen aus Anatolien und Syrien. EPRO 35. Leiden-New York 1973.

= R. FLEISCHER: Artemis Ephesia. In: LIMC II. Zürich 1984, 755-763.

$=$ R. FLEISCHER: Die Kultstatue der Artemis von Ephesos und werwandte Götterbilder. In: SEIPEL 2008, $25-43$.

= R. FLEISCHER: Artemis Ephesia. In: LIMC Suppl. Zürich 2009, 91-93.

$=$ R. FLEISCHER: Die Amazonen und das Asyl des Artemisions von Ephesos. In: Amazonen zwischen Griechen und Skythen: Gegenbilder in Mythos und Geschichte. Hrsg.: Ch. Schubert, A. Weiss. Berlin-New York 2013, 259-265.

$=$ G. Forstenpointer-M. Kerschner-U. Muss: Das Artemision in der späten Bronzezeit und der frühen Eisenzeit. In: Die Archäologie der ephesischen Artemis. Gestalt und Ritual eines Heiligtums. Hrsg.: U. Muss. Wien 2008, 33-47.

= D. FraYER-Griggs: The beasts at Ephesus and the cult of Artemis. Harvard Theological Review 106 (2013) 459-477.

= Z. GoceVA: Hekate. In: LIMC VII/1. Zürich 1992, 1018-1019.

$=\mathrm{R}$. GORDON: The real and the imaginary. Production and religion in the Graeco-Roman World. In:

R. Gordon: Image and Value in the Graeco-Roman World. Studies in Mithraism and religious art. Collected studies 551. Aldershot 1996, 5-34.

$=$ H. P. HahN-H. Weiss: Mobility, Meaning and Transformations of Things. Shifting contexts of material culture through time and space. Oxford 2013.

= A. Hermary: Polos a décor en relief appartenant a une grande statue d'Artémis éphésienne. In: César, le Rhone pour mémoire: vingt ans de fouilles archeologique. Dir.: L. Long, P. Picard. Arles 2009, 136-139.

= G. HöLBL: Ägyptisches Kulturgut in archaischen Artemision. In: Die Archäologie der ephesischen Artemis. Gestalt und Ritual eines Heiligtums. Hrsg.: U. Muss. Wien 2008, 209-222.

= D. KNIBBE: Die zweite Kaiserneokorie und der Wandel des Erscheinungsbildes der Artemis Ephesia. Die Via Sacra in der Bildersprache ihres Polos. In: Via Sacra Ephesiaca II. Grabungen und Forschungen 1992 und 1993. Hrsg.: D. Knibbe, H. Thür. Berichte und Materialien des Österreichischen Archäologischen Institutes 6. Wien 1995, 96-99.

= D. Mattingly: Identities in the Roman world: discrepancy, heterogeneity, hybridity, and plurality. In: Roman in the Provinces Art on the Periphery of Empire. Eds.: L. Brody, G. Hoffman. Boston 2014, 35-59.

$=$ G. MacLean Rogers: The Mysteries of Artemis of Ephesos. Cult, Polis, and Change in the GrecoRoman World. New Haven-London 2012.

= V. MogA: Mercurius la Apulum. Apulum 41 (2004) 253-258

= V. MogA: Consideraţii asupra unor artefacte arheologice recuperate (Notes on some recovered archaeological artifacts). Patrimonium Apulense 7-8 (2008) 83-95.

= J. Murphy-O'Connor: St. Paul's Ephesus. Texts and Archaeology. Collegeville, MN 2008.

= U. Muss: Zur Geschichte des Artemisions. In: Die Archäologie der ephesischen Artemis. Gestalt und Ritual eines Heiligtums. Hrsg.: U. Muss. Wien 2008, 47-57.

= U. Muss: Kultbild und Statuetten - Göttinnen im Artemision. In: Die Archäologie der ephesischen Artemis. Gestalt und Ritual eines Heiligtums. Hrsg.: U. Muss. Wien 2008, 63-67. 
NEMETI 2012

NeMETI 2013

OTA 2012

OTA-Bolog 2016

PISO et al. 2011

Pop 1990-1993

PoPA 1975

PorTefaIx 1993

RANSOME 2004

SARIAN 1992

SCHÄFER 2004

SEIPEL 2008

SimON 2009

SteuerNAGEl 2001

STRELAN 1996

ȘTEFĂNESCU 2003

SZABÓ 2016

THIERSCH 1935

TuRCSÁN-TóTH 2006

TURCSÁN-TóTH 2015

ŢEPOSU-MARINESCU-PoP 2000

WIEGELS 2013

WILLIAMSON 2005

ZEFLEANU 1949
= S. NEMETI: Dialoguri păgâne [Pagan dialogues]. Iaşi 2012.

= S. NemETi: La religione della Dacia romana nella storiografia recente. In: Sguardi interdisciplinari sulla religiosità dei Geto-Daci. Ed. M. Taufer. Freiburg 2013, 137-155.

$=$ R. OTA: De la canabele legiunii a XIII-a Gemina la Municipium Septimium Apulense. Alba Iulia 2012.

$=$ R. OTA-A. Bolog: A bronze statuette of Minerva discovered at Apulum (Alba county/RO). In press.

= I. PISO-O. ȚENTEA: Un nouveau temple palmyrénien à Sarmizegetusa. Dacia N.S. 55 (2011) 111-121.

= C. Pop: Bronzuri figurate în Dacia romană: repertoriu apulens (Figurative bronzes in Roman Dacia: repertory from Apulum). Apulum 27-30 (1990-1993) 223-226.

= A. PopA: Oraşul roman Apulum (The Roman City of Apulum). Ed. M. Trandafir. Alba Iulia 1975, 38-103.

= L. Portefaix: Ancient Ephesus: Processions as media of religious secular propaganda. In: The Problem of Ritual: Based on Papers Read at the Symposium on Religious Rites Held at Âbo, Finland, on the $13^{\text {th }}-16^{\text {th }}$ of August 1991. Ed.: T. Ahlbäck. Scripta Instituti Donneriani Aboensis 15. Âbo 1993, 195-210.

= H. Ransome: The Sacred Bee in Ancient Times and Folklore. Dover Publications Mineola. New York, 2004

= M. SARIAN: Hekate. In: LIMC VII/1. Zürich 1992, 985-1018.

= A. SCHÄFER: The diffusion of religious belief in Roman Dacia: a case-study of the gods of Asia Minor. In: Roman Dacia. The Making of a Provincial Society. Eds: I. Haynes, W. Hanson. JRA SupplSer 56. Portsmouth, RI 2004, 159-190.

= W. SEIPEL: Das Artemision von Ephesos. Heiliger Platz einer Göttin. Wien-Istanbul 2008.

= S. SimON: Hekate. In: LIMC Suppl. Zürich 2009, 238-239.

= D. STEuernagel: La recezione dei culti orientali ad Aquileia. In: Orizzonti del sacro. Culti e santuari antichi in Altino e nel Veneto Orientale Atti del Convegno Venezia, 1-2 dicembre 1999. A cura di Giovannella Cresci Marrone e Margherita Tirelli. Studi e ricerche sulla Gallia Cisalpina 11. Roma 2001, 317-326.

= R. Strelan: Paul, Artemis, and the Jews in Ephesus. Berlin-New York 1996

= A. ȘTEFĂNESCU: Cultul zeiţei Hecate în Dacia romană - The cult of Hecate in Roman Dacia. Analele Banatului 10-11 (2003) 131-140.

= Cs. SzABó: Béla Cserni and the beginnings of urban archaeology in Alba Iulia. Cluj-Napoca 2016.

= H. THIERSCH: Artemis Ephesia: Eine archäologische Untersuchung. Berlin 1935.

$=$ Zs. TuRCSÁN-Tóth: Istennő(k) az Artemiszionban [Godess(es) in Artemision]. Studia Caroliensia 2006/3-4, 181-187.

= Zs. TuRCSÁN-TóTH: Alapvetés az Artemis Ephesia szobrok ikonográfiai programjának elemzéséhez. Ph.D. thesis. Online: http://www.idi.btk.pte.hu/dokumentumok/disszertaciok/turcsantothzsuzsannaphd.pdf. Last accessed: 1.05.2016.

= L. ŢEPOSU-MARINESCU-C. PoP: Statuete de bronz din Dacia romană (Bronze statuettes from Roman Dacia). Bucureşti 2000.

$=$ R. WIEGELS: Der Sonnengott in Hannover. Zu einer Bemerkenswerten statuette des Sol. Varus Kurier 15 (2013) 1-5.

= G. Williamson: Mucianus and the touch of the Miraculous. Pilgrimage and tourism in Roman Asia Minor. In: ELSNER-RUTHERFORD 2005, 219-252.

= E. ZEFLEANU: Note epigrafice din Apulum II (Epigraphic notes from Apulum II). Apulum 3 (1949) $170-179$. 